\title{
Microbiological quality of grain cultivated in the North Caucasus region in 2019
}

\author{
Tatiana Gagkaeva ${ }^{1, *}$, Olga Gavrilova ${ }^{1}$, Aleksandra Orina ${ }^{1}$, Aleksey Burkin ${ }^{2}$, and Kharon Khusaynov ${ }^{3}$ \\ ${ }^{1}$ Laboratory of Mycology and Phytopathology, All-Russian Institute of Plant Protection, St. Petersburg, Pushkin 196608, Russia \\ ${ }^{2}$ Mycotoxicology Laboratory, All-Russia Research Institute of Veterinary Sanitation, Hygiene, and Ecology - Skryabin and Kovalenko \\ Federal Scientific Center All-Russia Research Institute of Experimental Veterinary Medicine, 123022 Moscow, Russia \\ ${ }^{3}$ Department of Landscape Agriculture, Chechen Research Institute of Agriculture, Grozny, Gikalo village 366021, Russia
}

\begin{abstract}
The microbiological quality of 23 grain samples of wheat and barley harvested in the North Caucasus in 2019 was analysed on the basis of the percentage of grains infected by fungi and the amounts of trichothecene-producing Fusarium DNA and Alternaria DNA. The mycotoxins produced by these fungi were also determined. Alternaria and Fusarium fungi were the predominant fungi in the mycobiota of grain, accounting for at $93 \%$ and $14 \%$ of the observed fungi, respectively. Alternariol produced by Alternaria fungi was detected in $65 \%$ of samples, and its content (11-675 ppb) was positively correlated with the abundance of fungi of section Alternaria in grain. F. langsethiae was found in wheat grain from the Chechen Republic for the first time. The T- 2 toxin produced by this fungus was found in $25 \%$ of samples, and its content in one barley grain reached $650 \mathrm{ppb}$, which exceeded the permitted level for this mycotoxin. The mycotoxins deoxynivalenol and zearalenone, which are mainly produced by $F$. graminearum, were also identified in $13 \%$ of the grain samples. The positive correlation between the amounts of both these mycotoxins and the DNA of Tri-Fusarium was established.
\end{abstract}

\section{Introduction}

The main export-oriented grain-producing region in Russia is the North Caucasus (Kuban, Don and Stavropol Territories), where $25 \%$ of the total annual grain production in Russia takes place. The microbiological quality of grain from this region has been analysed for many years, and the situation of the contamination of grain by toxin-producing fungi is well known [1, 2].

Several surveys of mycotoxin contamination of grain in the Southern European region of Russia have been conducted [3, 4]. In Krasnodar Territory in 2002-2003, grain was mainly contaminated by the $\mathrm{T}-2$ toxin $(85.0 \%)$ and was less often contaminated by DON $(8.3 \%)$ and ZEN $(0.7 \%)$. The T-2 toxin was detected more often in barley grain than in wheat [3].

Unfortunately, the available information about the fungal infection and mycotoxin contamination of cereals cultivated under natural environmental conditions in different Republics of the North Caucasus region is limited.

The urgency of the need for regular control measures for the mycotoxicological quality of produced grain is indicated by the results of the analysis of 37 grain samples of wheat and barley grown in North Ossetia in 2004-2007. High levels of the T-2 toxin (4-223 ppb), DON (40-2510 ppb) and ZEN (50-140 ppb) were detected in $68 \%, 59 \%$ and $8 \%$ of the samples, respectively [3].

The Chechen Republic (or Chechnya) is located in the eastern part of the North Caucasus, which is characterized by considerable variety of climatic conditions, ranging from arid, temperate continental conditions to cold, humid highlands, so the analysis of grain grown in the territory of the Republic is of particular interest.

Cereals occupy approximately $50 \%$ of the sown area in Chechnya. According to official information from the Ministry of Agriculture of the Chechen Republic, in 2019, the harvested area of cereals was 110 thousand ha, and the yield of cereal crops averaged $2.43 \mathrm{t} / \mathrm{ha}$, which was significantly lower than in the previous year [5]. This loss was caused by the death of a significant portion of winter and spring crops due to drought beginning in autumn.

The microbiological quality of grain is influenced by many factors and not only by the meteorological conditions prevailing during grain ripening and harvesting. Other determining factors are the applied cultivation technology, seed quality and contamination of obtained crops by fungi.

Temperature and humidity during the vegetation period and during crop storage are key factors affecting the ability of fungi to produce mycotoxins, which are fungal secondary metabolites and have various acute and chronic effects on human and animal health. Mycotoxins

\footnotetext{
Corresponding author: t.gagkaeva@mail.ru
} 
represent an important risk, as most consumers worldwide are exposed to persistent levels of multiple mycotoxins in food, especially in cereal products.

The production of mycotoxins by fungi is a pronounced species-specific characteristic; therefore, knowledge about the species composition of fungi allows predicting the spectrum of toxic metabolites contaminating grain.

Widespread groups of Alternaria and Fusarium fungi infect many crop plants, including cereals. Alternaria is a group of ubiquitous fungi that can penetrate grain in the early stages of growth. These fungi located inside the plant tissue are usually not visible and do not causes apparent harm to the host; nevertheless, some Alternaria species can produce dangerous mycotoxins [6-9]. Among the toxic secondary metabolites of Alternaria fungi, alternariol $(\mathrm{AOH})$ is one of the most important mycotoxins due to its frequent occurrence in grain samples.

The Alternaria species that are most actively involved in $\mathrm{AOH}$ contamination in cereals and fodder remain unclear [9-13]. $\mathrm{AOH}$ is cytotoxic and induces apoptotic cell death through the mitochondrial pathway [14]. However, the amounts of Alternaria mycotoxins in cereal grains are not regulated in Russia.

When grain is colonized by toxin-producing Fusarium fungi, there is a significant risk of contamination with mycotoxins, and the safety of the consumption grain can consequently be greatly reduced [15]. In the Russian Federation, according to food and feed safety control standards, the maximum permissible limits (MPL) of mycotoxins produced by Fusarium fungi have been established for cereal grains and their processed products [16].

The MPL for deoxynivalenol (DON) and zearalenone (ZEN), mainly produced by $F$. graminearum and $F$. culmorum, cannot be higher than $1000 \mathrm{ppb}$. The MPL of the T-2 toxin, which is one of the most toxic Fusarium secondary metabolites to both humans and animals [15, 17] and is produced by $F$. sporotrichioides and $F$. langsethiae, is $100 \mathrm{ppb}$.

The analysis of the fungal species composition and mycotoxin contamination associated with cereal grain harvested in the territory of the Chechen Republic has not been previously conducted.

The aim of this study was to evaluate microbiological quality and examine the amounts of mycotoxins in the grain of wheat and barley grown in the North Caucasus region in 2019.

\section{Materials and Methods}

In 2019, twenty wheat and three barley grain samples originating from the Chechen Republic ( $n=19)$, Republic of Ingushetia $(n=3)$ and Republic of Dagestan $(n=1)$ were analysed. Eight samples were collected in the dry steppe, 5 in the steppe, 8 in the forest-steppe and two in mountain-forest biomes.

To evaluate the latent infection of grain and for the subsequent identification of the fungal species composition, 100-200 grains of each sample were surface sterilized with $5 \% \mathrm{NaOCl}$ and placed on potatosucrose agar medium (PSA) in a Petri dishes. After 7 days, the number of fungal colonies grown from the grain was recorded to determine their species affiliations.

The taxonomic status of strains was revealed according to the sum of their macro- and micromorphological characters [18-21]. The species and origin of strains included in the study are shown in table 1. The strains are maintained in the collection of the Laboratory of Mycology and Phytopathology (AllRussian Institute of Plant Protection, St. Petersburg, Russia).

Grain samples were ground separately with a laboratory mill (IKA, Germany), and two samples of flour were selected: a $200 \mathrm{mg}$ sample was used for DNA isolation, and a $1 \mathrm{~g}$ sample was used for mycotoxin extraction.

DNA from flour samples was isolated with a reagent kit (TermoFisher Scientific, Lithuania). TaqMan quantitative PCR (qPCR) was performed using specific primers and probes for the detection of the DNA of Fusarium fungi producing trichothecene mycotoxins (Tri-Fusarium) [22] and the DNA of Alternaria fungi [23]. The reactions were carried out in a $20 \mu \mathrm{l}$ volume containing $10 \mu \mathrm{l}$ of $2 \times$ TaqMan Master Mix (AlkorBio, Russia), each primer at $300 \mathrm{nM}$, a fluorescent probe at $100 \mathrm{nM}$ (Evrogen, Russia) and $2 \mu \mathrm{l}$ of the corresponding DNA solution.

Mycotoxins were extracted with $5 \mathrm{~mL}$ of an acetonitrile:water mixture $(84: 16$, v/v) for $14-16 \mathrm{~h}$. The amounts of mycotoxins were determined by using certified test-systems for ELISA according to the protocol of the manufacturer (VNIIVSGE, Russia).

Data were analysed by using Microsoft Office Excel 2007 and Statistica 10.0. For the determination of significant differences among samples, a generalized linear mixed model analysis of variance followed by Tukey's test was used. Differences were considered significant at $\mathrm{p}<0.05$.

\section{Results and Discussion}

The fungal species composition in the mycobiota of the analysed grain samples was abundant and diverse. Alternaria and Fusarium fungi occurred most often in comparison with other fungi associated with cereal grain harvested in Chechnya.

The other fungi that are usually present in the mycobiota of grain were represented by Epiccocum, which was detected in $89.5 \%$ of samples, with occurrence ranging from 1-18\%; Nigrospora, in $63.1 \%$ of samples (1-9\%); Aspergillus, in $52.5 \%$ (1-4\% of infected grain); and Arthrinium in 15,8\% (1-3\%).

The rate of the infection of grain by Alternaria fungi ranged from 55 to $93 \%$. The frequency of occurrence of the species belonging to section Alternaria (94\% of all Alternaria isolates) was much higher than that of the species of section Infectoriae (6\%).

The infection of grain by fungi of section Alternaria was revealed in all grain samples and varied in the range of $52-89 \%$. At the same time, only $78 \%$ of the samples 
were infected by fungi of section Infectoriae (ranging from 1 to $21 \%$ ). DNA of Alternaria fungi was found in all grain samples, accounting for $(4-75) \times 10^{-5} \%$ of the total DNA on average, without any differences between grain samples collected in the different biomes (Table 1).

The AOH produced by Alternaria fungi was detected in $65 \%$ of the samples in amounts of 11-675 ppb.
However, $35 \%$ of all analysed grain samples originating from the steppe and dry-steppe zones were free of $\mathrm{AOH}$. Positive correlations between the percentage of grains infected with Alternaria section Alternaria fungi and the amount of Alternaria DNA ( $\mathrm{r}=0.47)$ as well as with the content of $\mathrm{AOH}(\mathrm{r}=0.46)$ were established.

Table 1. The grain infection by Alternaria and Fusarium fungi and mycotoxins contamination of grain from different climatic zones in the North Caucasus region in 2019

\begin{tabular}{|c|c|c|c|c|c|c|c|c|}
\hline \multirow{3}{*}{$\begin{array}{c}\text { Climatic zona } \\
\text { (number of } \\
\text { samples) }\end{array}$} & \multicolumn{2}{|c|}{$\begin{array}{c}\text { Infected grain, } \\
\%\end{array}$} & \multicolumn{2}{|c|}{$\begin{array}{c}\text { Amounts of DNA } \times 10^{-5} \text {, } \\
\% \text { of the total DNA }\end{array}$} & \multicolumn{4}{|c|}{$\begin{array}{c}\text { Amounts of mycotoxins, } \\
\text { ppb }\end{array}$} \\
\hline & \multicolumn{8}{|c|}{ Occurrence in grain samples, $\%$ and (the range of values) } \\
\hline & Alternaria & Fusarium & $\begin{array}{c}\text { Tri- } \\
\text { Fusarium }\end{array}$ & Alternaria & DON & $\begin{array}{c}\mathrm{T}-2 \\
\text { toxin }\end{array}$ & ZEN & $\mathrm{AOH}$ \\
\hline Dry-steppe $(\mathrm{n}=8)$ & $\begin{array}{c}100 \\
(54-96)\end{array}$ & $\begin{array}{l}12.5 \\
(14)\end{array}$ & $\begin{array}{c}37.5 \\
(3-13)\end{array}$ & $\begin{array}{c}100 \\
(4-74)\end{array}$ & 0 & $\begin{array}{c}25 \\
(15.650)\end{array}$ & 0 & $\begin{array}{c}37.5 \\
(16-42)\end{array}$ \\
\hline Steppe $(\mathrm{n}=5)$ & $\begin{array}{c}100 \\
(59-96)\end{array}$ & $\begin{array}{c}20 \\
(1-2)\end{array}$ & $\begin{array}{c}40 \\
(3-6)\end{array}$ & $\begin{array}{c}100 \\
(16-46)\end{array}$ & 0 & $\begin{array}{c}40 \\
(8.66)\end{array}$ & $\begin{array}{c}20 \\
(14)\end{array}$ & $\begin{array}{c}40 \\
(11-102)\end{array}$ \\
\hline $\begin{array}{l}\text { Forest- steppe } \\
(\mathrm{n}=8)\end{array}$ & $\begin{array}{c}100 \\
(60-94)\end{array}$ & $\begin{array}{c}50 \\
(1-8)\end{array}$ & $\begin{array}{c}25 \\
(6-29)\end{array}$ & $\begin{array}{c}100 \\
(32-75)\end{array}$ & $\begin{array}{l}12.5 \\
(40)\end{array}$ & $\begin{array}{c}12.5 \\
\text { (7) }\end{array}$ & $\begin{array}{c}25 \\
(10.40)\end{array}$ & $\begin{array}{c}100 \\
(12-675)\end{array}$ \\
\hline $\begin{array}{l}\text { Mountain- forest } \\
(\mathrm{n}=2)\end{array}$ & $\begin{array}{c}100 \\
(66-81)\end{array}$ & $\begin{array}{r}100 \\
(5-9)\end{array}$ & 0 & $\begin{array}{c}100 \\
(33-70)\end{array}$ & 0 & $\begin{array}{l}50 \\
(2)\end{array}$ & 0 & $\begin{array}{c}100 \\
(30-35)\end{array}$ \\
\hline
\end{tabular}

The maximum rate of the infection of the grain by Fusarium fungi reached $14 \%$ in the grain sample of wheat from the dry steppe zone. At least 11 Fusarium species were identified in grain: $F$. acuminatum, $F$. avenaceum, $F$. equiseti, $F$. graminearum, $F$. langsethiae, $F$. poae, $F$. proliferatum, $F$. semitectum, $F$. sporotrichioides, $F$. tricinctum, and $F$. verticillioides. DNA of Tri-Fusarium fungi was detected in 7 samples, and the amount of fungal DNA ranged from $3.1 \times 10^{-5}$ to $2.9 \times 10^{-4} \%$ of the total DNA.

Arid conditions in the 2019 growing season resulted in lower infection with $F$. graminearum, which is a typical pathogen of cereals in the North Caucasus region and the main producer of DON and ZEN. This pathogen was detected in $30 \%$ of samples, with infection range within $1-6 \%$. DON was found in one grain sample of wheat from the forest-steppe zone at $40 \mathrm{ppb}$. ZEN was found in three samples of wheat from the steppe and forest-steppe zones at 10-40 ppb. A positive correlation between infection of grain with $F$. graminearum and the amounts of DON and ZEN ( $\mathrm{r}=0.64$ and $\mathrm{r}=0.56$, respectively) was revealed.

Moreover, a positive correlation between the amount of Tri-Fusarium DNA and both DON and ZEN amounts $(r=0.88$ and $r=0.79$, respectively) was established. The obtained data are in accordance with the results of our studies carried out previously, in which a strong positive relationship between $F$. graminearum and its toxic secondary metabolites was demonstrated $[24,25]$.

The key finding of the study was the identification of F. langsethiae in $13 \%$ of grain samples of wheat grown in the Chechen Republic, where this species was not previously detected. Recently, F. langsethiae was found in wheat grain from the Krasnodar and Stavropol regions, and grain infection by this fungus reached $5 \%$ [1].

This species does not cause obvious symptoms of the head, and it is impossible to visually detect the infection of cereals by $F$. langsethiae in the field, in contrast to what is observed for $F$. graminearum, which causes visually apparent symptoms [26]. F. langsethiae is a strong producer of the T-2 toxin, as is $F$. sporotrichioides [27-29]. F. sporotrichioides was detected in $22 \%$ of the samples.

Twenty-six percent of the grain samples were contaminated by the T-2 toxin, in amounts ranging from 7 to $650 \mathrm{ppb}$. The maximum level of the T-2 toxin was detected in the grain of barley from the dry steppe zone, which exceeded the MPL for this mycotoxin by 6.5 times. In our study, the relationship between the occurrence of Fusarium species producing the T-2 toxin and its concentration in grain was not detected, apparently due to the low rate of grain infection by these species (not higher than 3\%). 


\section{Conclusion}

Clarification of the species composition of fungi colonizing grain cereals cultivated in a particular region will improve the technology related to the use of contaminated grain for seed, food and fodder purposes. The significant infection of grain with toxin-producing fungi demonstrates the problem of mycotoxins in grainproducing regions of Russia as well as the need to control the quality of raw grain materials used for the production of food and feed.

This study shows that even in a dry growing season, there is a risk of grain contamination with mycotoxins, particularly toxic metabolites of Alternaria and Fusarium species, which do not require high humidity. At the same time, the presence of pathogenic $F$. graminearum in the grain suggests that in growing seasons with sufficient moisture, the grain contamination by DON and ZEN can be significantly higher than the MPL.

The dynamics and hazards of grain contamination with mycotoxins in each territory can be evaluated only in long-term annual studies, since they are determined not only by the degree of fungal disease spreading but also by the possibility of realizing the toxigenic potential of pathogens, which is influenced by many environmental factors.

This study was supported by the Russian Science Foundation (project no. 19-76-30005).

\section{References}

1. T.Yu. Gagkaeva, Ph.B. Gannibal, O.P. Gavrilova, Prot. Quar. Plants, 5, 37 (2011)

2. T.Yu. Gagkaeva, O.P. Gavrilova, A.S. Orina, I.B. Ablova, L.A. Bespalova, Plant Biotechnology and Breeding, 1, 7 (2018)

3. G.P. Kononenko, A.A. Burkin, Agricultural Biology, 44, 81 (2009)

4. G.P. Kononenko, A.A. Burkin, E.V. Zotova, M.I. Ustyuzhanina, A.M. Smirnov, Russ. Agric. Sci., 44, 137 (2018)

5. Retrieved from: https://chechnyatoday.com/news/ 328474

6. H. Lee, A. Patriarca, N. Magan, Mycobiol., 43, 93 (2015)

7. B. Andersen, E. Krøger, R.G. Roberts, Mycol. Res., 106, 170 (2002)

8. K. Zhao, B. Shao, D. Yang, F. Li, J. Zhu, PLoS ONE, 10, e0132019 (2015)

9. S.M. Tralamazza, K.C. Piacentini, C.H.T. Iwase, L.O. Rocha, Curr. Opin. Food Sci., 23, 57 (2018)
10. A.A. Burkin, G.P. Kononenko, Appl. Biochem. Microbiol., 47, 72 (2011)

11. T. Zwickel, S.M. Kahl, M. Rychlik, M.E.H. Müller, Front. Microbiol., 9, 1368 (2018)

12. Y. Li, Z. Wang, R.C. Beier, J. Shen, D. De Smet, S. De Saeger, S. Zhang, J. Agr. Food Chem., 59, 3441 (2011)

13. Ph.B. Gannibal, Plant Protection News, 6, 82 (2007)

14. S. Fraeyman, S. Croubels, M. Devreese, G. Antonissen, Toxins, 9, 228 (2017)

15. J.P.F. D'Mello, C.M. Placinta, A.M.C. Macdonald, Anim. Feed Sci. Tech., 80, 183 (1999)

16. TR CU 021/2011 Technical Regulations of the Customs Union "On food safety" with the changes 2019 August 8.

17. Y. Ueno, Fund. Appl. Toxicol., 4, S124 (1984)

18. M.B. Ellis, Dematiaceous Hyphomycetes (Commonwealth Mycological Institute, Kew, Surrey, England, 1971)

19. J.C. Frisvad, B. Andersen, U. Thrane, Mycol. Res., 112, 231 (2008)

20. R. Samson, E. Hoerstra, J. Frisvad, O. Filtenborg, Introduction to food- and airborne fungi (The Netherlands, 2002)

21. W. Gerlach, H.I. Nirenberg, The genus FusariumA Pictorial Atlas (Mitteilungen aus der Biologischen - und Forstwirtschaft, Berlin-Dahlem, 1982)

22. T. Yli-Mattila, S. Paavanen-Huhtala, M. Jestoi, P. Parikka, V. Hietaniemi, T Gagkaeva., T. Sarlin, A. Haikara, S. Laaksonen, A. Rizzo, Arch. Phytopathol. Plant Protect., 41, 243 (2008)

23. A.S. Orina, O.P. Gavrilova, T.Yu. Gagkaeva, MIR J., 5, 78 (2018)

24. N.P. Shipilova, O.P. Gavrilova, T.Yu. Gagkaeva, Plant Protection News, 4, 27 (2014)

25. T. Gagkaeva, O. Gavrilova, A. Orina, Y. Lebedin, I. Shanin, P. Petukhov, S. Eremin, Toxins, 11, 252 (2019)

26. I.S. Hofgaard, H.U. Aamot, T. Torp, M. Jestoi, V.M.T. Lattanzio, S.S. Klemsdal, C. Waalwijk, T. van der Lee, G. Brodal, World Mycotoxin J., 9, 365 (2016)

27. S.M. Imathiu, S.G. Edwards, R.V. Ray, M.A. Back, J. Phytopathol., 161, 1 (2013)

28. M. Kokkonen, M. Jestoi, A. Laitila, Mycotoxin Res., 28, 25 (2012)

29. L. Nazari, E. Pattori, V. Terzi, C. Morcia, V. Rossi, Food Microbiol., 39, 19 (2014) 